\title{
RELATION OF HIGH MOLECULAR WEIGHT PROTEINS TO THE SEROLOGICAL REACTIONS IN RHEUMATOID ARTHRITIS*
}

\author{
BY \\ E. C. FRANKLIN, H. G. KUNKEL, H. J. MÜLLER-EBERHARD, AND \\ H. R. HOLMAN \\ The Rockefeller Institute for Medical Research, New York, N.Y.
}

(RECEIVED FOR PUBLICATION JULY 22, 1957)

The ability of sera from patients with rheumatoid arthritis to potentiate the agglutination of sensitized particulate bodies has been recognized since Cecil, Nicholls, and Stainsby (1931) noted the agglutination of certain strains of streptococci by these sera. More recently this property has been employed as the basis of a number of clinical tests for the diagnosis of rheumatoid arthritis. The tests most frequently used are the sensitized sheep cell agglutination, Fraction II agglutination, latex fixation, $\mathrm{Rh}$ agglutination, and gamma-globulin precipitation tests. The reaction common to all these tests seems to be the interaction of the rheumatoid factor or factors present in serum with gamma-globulin attached to a particulate body. The particulate body probably acts only as a carrier for the gammaglobulin since it has been demonstrated by Epstein, Johnson, and Ragan (1955) that Fraction II gammaglobulin can form a precipitate with rheumatoid sera directly. This is especially true when the gammaglobulin has previously been altered by heating or a number of other procedures (Franklin, Holman, Müller-Eberhard, and Kunkel, 1957).

Normal human gamma-globulin contains two major ultracentrifugal components. The main one has a sedimentation rate of $7 \mathrm{~S}$, while the minor one, which normally makes up from 5 to 10 per cent. of the total gamma-globulin, has a sedimentation coefficient of 19S (Muller-Eberhard, Kunkel, and Franklin, 1956). It has been demonstrated by numerous observers, particularly Svartz and Schlossman (1954) and by Ziff, Brown, Lospalluto, Badin, and McEwen (1956), that the rheumatoid factor is a gamma-globulin and that it can be concentrated in the euglobulin fraction of serum. Since the euglobulin fraction is rich in the minor high molecular weight fraction of gamma-globulin, it seemed

* Paper presented at the IX International; Congress of Rheumatology at Toronto,, in June, 1957. likely that the rheumatoid factor might be associated with a protein of high molecular weight. An ultracentrifugal study of sera and serum fractions from patients with rheumatoid arthritis was therefore undertaken in an effort further to characterize the rheumatoid factors responsible for the positive serological tests. Each of these was found to be of high molecular weight. In addition, it was possible to detect in the sera of certain of patients with rheumatoid arthritis the presence of an unusual high molecular weight protein complex (Franklin and others, 1957).

\section{Materials and Methods}

These are similar to those previously described (Franklin and others, 1957) and will be outlined only briefly.

(1) Ultracentrifugation.-Analytical examination of sera and protein fractions was carried out in a Spinco Model E ultracentrifuge. Preparative density gradient ultracentrifugation was performed in a Spinco Model $\mathbf{L}$ ultracentrifuge in a swinging bucket rotor through a sucrose gradient. The distribution of gamma-globulins of different sedimentation rates was determined by a quantitative immunologic assay, using antisera against the major $7 \mathrm{~S}$ gamma-globulin and the minor $19 \mathrm{~S}$ gammaglobulin fractions; it was further checked by analytical ultracentrifugation of the recovered material.

(2) Electrophoresis.-Zone electrophoresis was carried out according to methods previously described, using starch as a supporting medium and barbital buffer $p \mathrm{H} 8 \cdot 6, \mathrm{~T}_{2} 0 \cdot 1$.

(3) Serologic Tests.-The gamma-globulin precipitation test was carried out with gamma-globulin heated at $63^{\circ}$ for 10 minutes as previously described. The sensitized sheep cell agglutination test was performed according to the method of Heller, Kolodny, Lepow, Jacobson, Rivera, and Marks (1955), the latex fixation test according to Singer and Plotz (1956) and the Rh agglutination test according to Waller and Vaughan (1956). 


\section{Results}

(1) Presence of a High Molecular Weight Complex in the Serum of Certain Patients with Rheumatoid Arthritis.-Fresh sera from 31 patients with rheumatoid arthritis and 37 sera from normal control subjects and from patients with a variety of diseases many of which were associated with abnormalities in the serum proteins were examined in the analytical ultracentrifuge. In all the sera examined a peak with a sedimentation coefficient of $19 \mathrm{~S}$ could be observed during the first hour of centrifugation at 52,640 r.p.m. This peak can be seen in normal serum (Fig. 1, opposite). In fourteen of the sera from patients with rheumatoid arthritis this peak divided into two parts. One of these sedimented with the normal 19S component. The other one sedimented more rapidly and has previously been called the 22S component (Franklin and others, 1957). In seven of these fourteen sera this component was present in concentrations between 75 and $350 \mathrm{mg}$. per cent., while in seven others it was present in amounts too small to be accurately measured and could be noted only as a distinct asymmetry preceding the 19S peak. The plasma was examined in two cases and was also shown to contain the component. Three sera from patients with rheumatoid arthritis with easily detectable amounts of this unusual complex are shown in Fig. 1 (opposite). None of the control sera contained measurable amounts of this high molecular weight material.
(2) Relationship of High Molecular Weight Complex to Serological Tests.-Table I demonstrates that, in general, there was some correlation between the amount of $22 \mathrm{~S}$ material and the intensity of the precipitation reaction and sheep cell agglutination reaction. Subsequent studies on many additional sera have confirmed this observation and have shown a similar relationship of the high molecular weight fraction to the latex fixation and $\mathrm{Rh}$ agglutination reactions. In every case sera that were most highly active by the serological tests contained measurable amounts of $22 \mathrm{~S}$ material. It appeared that the ultracentrifuge was relatively insensitive and that small amounts of $22 \mathrm{~S}$ material might be present but remain undetected in sera that were less positive in the serological reactions.

Further direct evidence demonstrating that the biologic activities were associated with a high molecular weight protein was obtained by density gradient high speed centrifugation of whole sera. Table II shows the results obtained with fractions obtained from one patient with rheumatoid arthritis. None of the activity by any of the serological tests was present in the top fractions which contained the bulk of the 7S gamma-globulin. (The albumin coloured with bromphenol blue was localized in Fraction II.) All the activity by each of the four tests was found near the bottom of the tubes in those fractions shown to contain all of the 19S gamma globulin as determined by a specific antiserum and less than 10 per cent. of the total gamma-globulin.

TABLE I

RELATIONSHIP OF THE 22S COMPONENT TO THE ACTIVITY IN THE GAMMA-GLOBULIN PRECIPITATION AND THE SHEEP CELL AGGLUTINATION TESTS. THE NUMBERS OF CASES ARE LISTED

\begin{tabular}{|c|c|c|c|c|c|c|c|c|c|c|c|c|c|c|}
\hline \multirow{2}{*}{\multicolumn{5}{|c|}{$\begin{array}{l}\text { 22S Material } \\
\text { (mg. per cent.) }\end{array}$}} & \multicolumn{5}{|c|}{ Gamma-Globulin Precipitation } & \multicolumn{5}{|c|}{$\begin{array}{c}\text { Sensitized Sheep Cell Agglutination } \\
\text { (Dilution) }\end{array}$} \\
\hline & & & & & Negative & $1+$ & $2+$ & $3+$ & $4+$ & $<64$ & 128 & 256 & 512 & 1,024 \\
\hline None & $\cdots$ & $\cdots$ & . & $\cdots$ & 6 & 8 & 2 & & & 3 & & 1 & 1 & \\
\hline$<75$ & $\cdots$ & $\cdots$ & $\cdots$ & $\cdots$ & & 3 & 4 & & & & 1 & 2 & 2 & \\
\hline $75-350$ & $\ldots$ & . & $\ldots$ & $\cdots$ & & & 3 & 2 & 2 & & & & 1 & 5 \\
\hline
\end{tabular}

TABLE II

DISTRIBUTION OF 7S AND 19S GAMMA-GLOBULIN DETERMINED IMMUNOLOGICALLY AND RHEUMATOID FACTORS IN FRACTIONS PREPARED FROM A HIGH TITRE RHEUMATOID ARTHRITIS SERUM BY DENSITY GRADIENT ZONE CENTRIFUGATION

\begin{tabular}{|c|c|c|c|c|c|c|}
\hline Fraction & $\begin{array}{l}\text { Reaction } \\
\text { with } \\
\text { 7S As. }\end{array}$ & $\begin{array}{l}\text { Reaction } \\
\text { with } \\
\text { 19S As. }\end{array}$ & $\begin{array}{c}\text { Sensitized } \\
\text { Sheep Cell } \\
\text { Agglutination }\end{array}$ & $\begin{array}{c}\text { Gamma-Globulin } \\
\text { Precipitation } \\
\text { Test }\end{array}$ & $\underset{\text { Agglutination }}{\text { Anti-Rh }}$ & $\begin{array}{c}\text { Latex } \\
\text { Fixation }\end{array}$ \\
\hline $\begin{array}{l}\text { II Albumin } \\
\text { III } \\
\text { IV } \\
\text { V Bottom }\end{array}$ & $\begin{array}{l}0 \\
2+ \\
4+ \\
1+ \\
1+\end{array}$ & $\begin{array}{l}0 \\
0 \\
0 \\
1+ \\
4+\end{array}$ & $\begin{array}{l}0 \\
0 \\
0 \\
1 / 64 \\
1 / 512\end{array}$ & $\begin{array}{l}0 \\
0 \\
0 \\
2+ \\
4+\end{array}$ & $\begin{array}{l}- \\
0 \\
1+ \\
4+\end{array}$ & $\begin{array}{l}\bar{r} \\
\frac{1}{1 / 1,024}\end{array}$ \\
\hline
\end{tabular}


Fig. 1.-Ultracentrifugal patterns of one normal serum and three sera from patients with rheumatoid arthritis. Each of the rheumatoid arthritis sera contains a second component sedimenting more rapidly than the $19 \mathrm{~S}$ peak visible in the control serum.
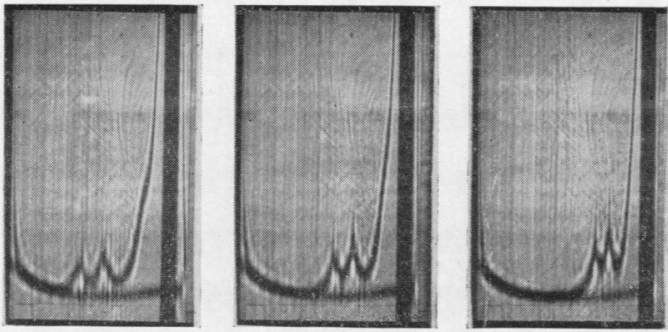

RHEUMATOID

ARTHRITIS
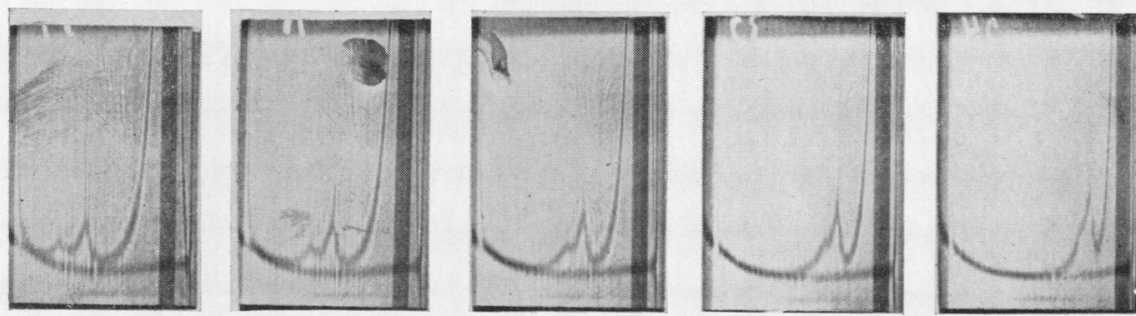

RHEUMATOID ARTHRITIS
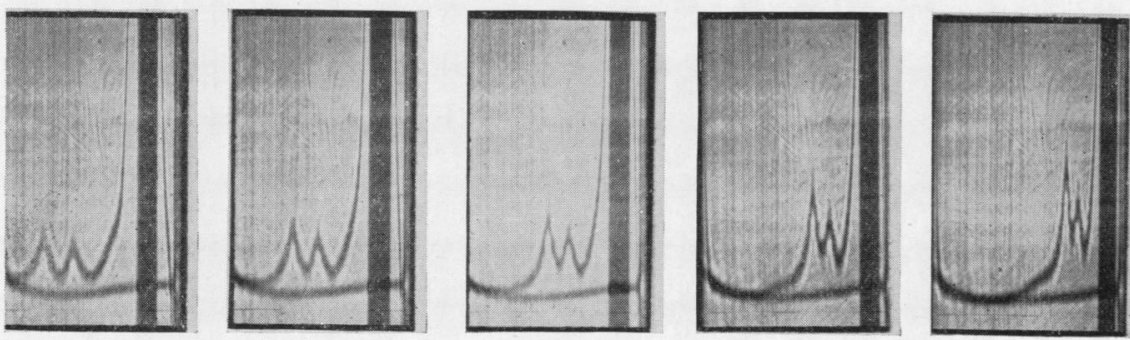

\section{RHEUMATOID} ARTHRITIS
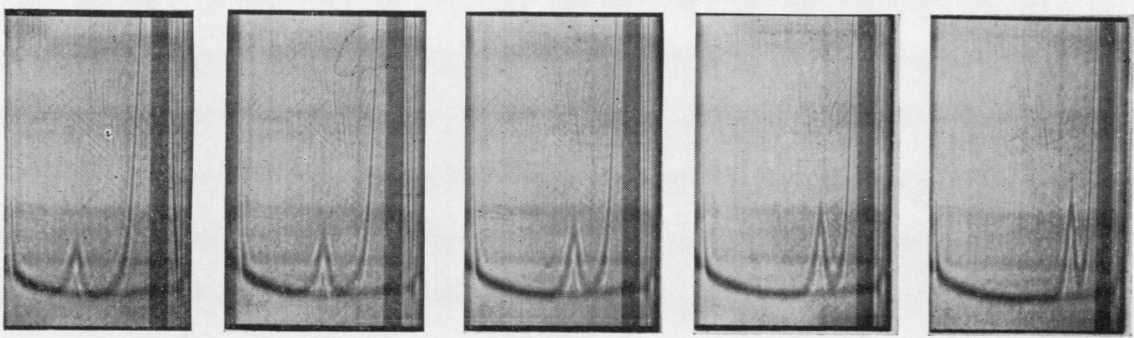

CONTROL
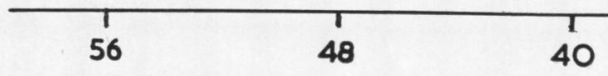

32

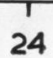

TIME (min.)

Numerous experiments of this type with both high and low titre sera always gave similar results with the serological activities in the bottom fractions. These experiments, while demonstrating an association of biologic activities with a high molecular weight protein, could not differentiate the $19 \mathrm{~S}$ and $22 \mathrm{~S}$ types.
The role of the $22 \mathrm{~S}$ component in the gammaglobulin precipitation reaction in particular and in the other serologic tests as well was further demonstrated by repeated absorption of positive sera with altered gamma-globulin. After several absorptions there was a great decrease in $22 \mathrm{~S}$ material in the supernatant with a concomitant loss of biologic activity. 
(3) Characterization of $22 S$ Complex.-Ultracentrifugal examination of various electrophoretically isolated protein fractions from sera of patients with rheumatoid arthritis showed the high molecular weight component to be associated only with the gamma-globulin fraction. Fig. 2 shows it to be distributed throughout the gamma-globulin fraction with a mobility slightly greater than that of the peak of the gamma-globulin. Similarly, the mobility of the four tests corresponded quite closely with that of the high molecular weight component. None of the other protein fractions contained any of the high molecular weight complex nor were they highly active in any of the serological tests.
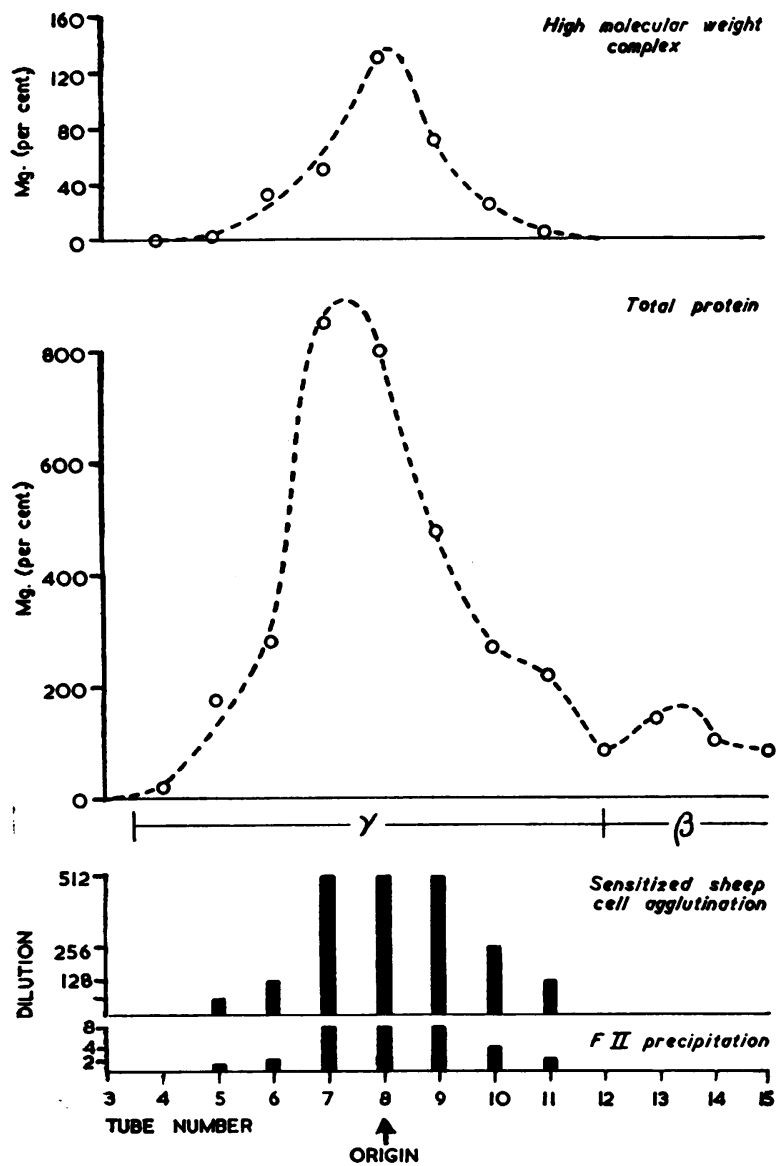

Fig. 2.-Electrophoretic distribution of the 22S component (above) and the activity in the sensitized sheep cell agglutination and gammaglobulin precipitation tests (below) compared with the protein distribution in the gamma- and beta-globulin fraction of a serum from a patient with rheumatoid arthritis.

Although evidence of heterogeneity in the ultracentrifuge suggested the presence of more than one molecular species in a number of instances, it was $\leftrightharpoons$ possible to determine an approximate sedimentation coefficient of the complex. The $s_{20}^{\circ}, \mathrm{w}$ was calculated $\bar{c}$ ? to be $22 \cdot 7 \mathrm{~S}$. Since it seemed possible that the $22 \mathrm{~S}$ component might represent a circulating complex composed of $19 \mathrm{~S}$ gamma-globulin and another? protein, attempts were made to dissociate it and to study the constituent parts. The $22 \mathrm{~S}$ materiaP proved to be readily dissociable by $4-6 \mathrm{M}$ urea, acido

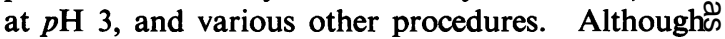
the initial observations were carried out on electro- $\overrightarrow{0}$ phoretically isolated gamma-globulin fractions, itsoon became evident that, for purposes of accuratew quantitation of the composition of the $22 \mathrm{~S}$ material the euglobulin fraction prepared by dilution of the serum with 10 volumes of deionized distilled waterwas superior. By this simple procedure it wasi possible to achieve considerable purification of the high molecular weight material.

Fig. 3 shows the appearance of the euglobulin fraction prepared from equal aliquots of a highly active rheumatoid serum and subsequently dissolvedp in equal volumes of saline, 30 per cent. urea, an glycine buffer $p \mathrm{H} 3$. It can be seen that, whereas the original euglobulin was composed of approxi-D mately equal amounts of $7 \mathrm{~S}, 19 \mathrm{~S}$, and $22 \mathrm{~S}$ material, the urea and acid have resulted in complete fise appearance of the $22 \mathrm{~S}$ peak with a concomitant increase in material sedimenting with the $7 \mathrm{~S}$ and fractions. Numerous observations of this types to be reported separately indicated that the $22 \mathrm{~S}$ material was a complex composed of approximatelyo 50 per cent. $7 \mathrm{~S}$ and 50 per cent. $19 \mathrm{~S}$ material $\mathbb{Q}$ Removal of the dissociating agent, especially if ureas
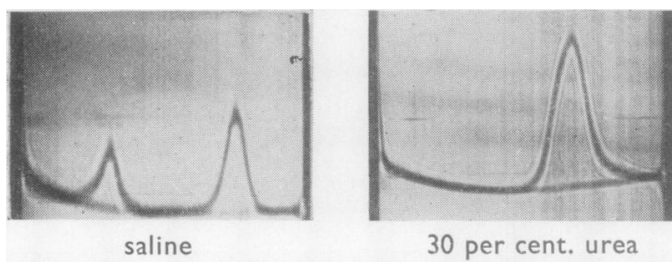

30 per cent. urea

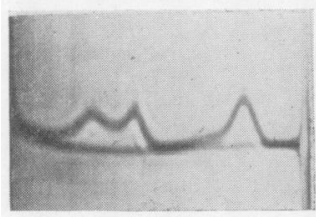

$\mathrm{pH} 3$

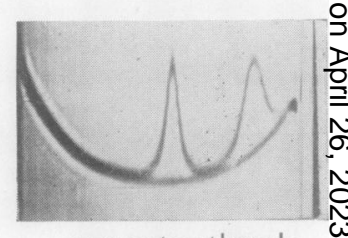

mercapto-ethanol

Fig. 3.-Ultracentrifugal patterns of the euglobulin fractions prepares from the serum of a patient with rheumatoid arthritis dissolved if 5 per cent. saline, acid pH 3, urea, and mercapto-ethanol. Th dissociation of the 22S peak in acid and urea is accompanied by ap increase in the amount of $7 \mathrm{~S}$ and $19 \mathrm{~S}$ material. The mercapto ethanol caused a loss of both $19 \mathrm{~S}$ and $22 \mathrm{~S}$ material. 
was used, has yielded highly active 19S fractions but has not yet resulted in reaggregation of the $22 \mathrm{~S}$ complex.

Dissociation of the $22 \mathrm{~S}$ complex also sometimes occurred during preparative purinication of the euglobulin fractions by density gradient centrifugation. The bottom fractions obtained by this procedure usually contained more than 90 per cent. 19S material and no detectable 7S and $22 \mathrm{~S}$ molecules. These preparations were extremely active by the four serological tests used. Similarly it was possible to obtain active $19 \mathrm{~S}$ material by gradient centrifugation of acid and urea-dissociated euglobulin fractions, particularly if urea was used. However, here too it was not possible to reform the $22 \mathrm{~S}$ complex by the addition of gamma-globulin, even if the $7 \mathrm{~S}$ material that was split off during dissociation was used.

\section{Dissociation with Sulphhydryl Compounds}

Recent observations (Ryle and Sanger, 1955; Deutsch and Morton, 1957) that many proteins consist of polypeptide chains linked by disulphide bridges suggested the possibility that the $22 \mathrm{~S}$ component and its active 19S derivative might owe their large size to such a linkage of smaller units. Mercapto-ethanol at a concentration of $0.1 \mathrm{M}$ and cysteine at a concentration of $0.1 \mathrm{M}$ caused complete dissociation of both the $22 \mathrm{~S}$ and the 19S components from euglobulin preparations. The result of one such experiment is shown in Fig. 3. All 19S and $22 \mathrm{~S}$ material disappeared and there was an increase in smaller proteins mostly of the $7 \mathrm{~S}$ class. With this dissociation there was a complete loss of serological activity both in the gamma-globulin precipitation test and in the sheep cell agglutination reaction.

\section{Analyses of the Fraction II - Rheumatoid Factor Precipitates}

Similar studies were carried out on the precipitates obtained by the addition of Fraction II gammaglobulin to rheumatoid sera. This precipitate, after washing, could be dissociated with urea and acid buffers to give soluble protein solutions. Examination in the ultracentrifuge showed that the precipitates were composed of $7 \mathrm{~S}$ and $19 \mathrm{~S}$ material in approximately equal amounts. Fig. 4 illustrates the ultracentrifuge pattern of two such dissolved precipitates. A similar composition was obtained when either urea or acid buffers were employed. Removal of the 7S material by density gradient centrifugation yielded 19S fractions soluble in isotonic saline which were highly active in each of the four serological tests. Of particular interest in these experiments was the finding that the material obtained by dissociation of the Fraction II - rheumatoid factor precipitate contained high agglutinating activity for sensitized sheep cells.

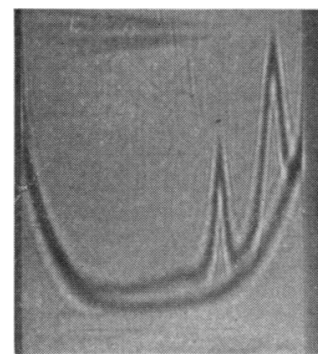

30 per cent. urea

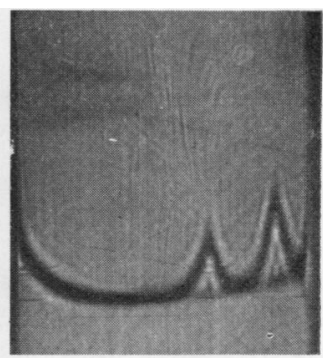

$\mathrm{pH} 3$
Fig. 4.-Ultracentrifugal patterns of two Fraction II-rheumatoid factor precipitates, one dissolved in acid and the other in urea, showing the presence of approximately equal amounts of $7 \mathrm{~S}$ and $19 \mathrm{~S}$ material.

\section{Discussion}

It is well known that sera from many patients with rheumatoid arthritis contain a factor or factors which potentiate certain agglutination reactions. This property has been used as the basis of a number of serological tests characteristic of this disease. The present study has demonstrated the presence of an unusual high molecular weight protein complex in the sera of certain patients with rheumatoid arthritis who are strongly positive by the serological tests. This material is associated with the gammaglobulin fraction, has a sedimentation rate of approximately $22 \mathrm{~S}$, and appears to be an easily dissociated complex of $7 \mathrm{~S}$ and 19S gamma-globulin fractions. Some evidence was obtained that the factors responsible for each of the serological tests were associated with the high molecular weight protein complex. This evidence was best for the gamma-globulin precipitation test. Occasional exceptions were encountered with the sheep cell reaction and further work is required to prove an absolute relationship.

The exact incidence of the $22 \mathrm{~S}$ component in sera from patients with rheumatoid arthritis is difficult to determine because of the insensitivity of the ultracentrifuge. It can be seen by direct ultracentrifugal examination as a well-defined peak or as a broad inhomogeneity in about one-third of the patients. However, since it is detectable only in those sera which are strongly positive by the much more sensitive serological tests, it seems probable that this material may be present in amounts too small to be detected in a greater percentage of the cases. This 
is in line with the known higher incidence of positive results by the serological tests.

The observation that the $22 \mathrm{~S}$ material is readily dissociated into two components with sedimentation rates of $7 \mathrm{~S}$ and $19 \mathrm{~S}$ indicates that it is a complex of $7 \mathrm{~S}$ and 19S material which exists in a soluble state in the sera of certain patients with rheumatoid arthritis. While the serological titres observed in whole serum seemed, in general, to parallel the amount of $22 \mathrm{~S}$ material present, it has not been ruled out that some activity could reside in the $19 \mathrm{~S}$ fraction of fresh serum. It has been readily possible to obtain highly active $19 \mathrm{~S}$ material both by dissociation of the $22 \mathrm{~S}$ complex and by centrifugal isolation from dissolved precipitates formed by the interaction of Fraction II gamma-globulin and rheumatoid factor. This would suggest that the true rheumatoid factor is a $19 \mathrm{~S}$ gamma-globulin, but that it exists in vivo primarily as a circulating complex. Since 19S gamma-globulin is known to contain a number of antibodies (Franklin and Kunkel, 1957), it is possible that the 19S gammaglobulin active in the rheumatoid tests is also an antibody. The nature of the 7S portion of the complex remains to be determined. The possibility that the $22 \mathrm{~S}$ material may be a circulating antigenantibody complex appears worthy of further investigation.

\section{Summary}

An unusual high molecular weight protein complex was detected in the sera of certain patients with rheumatoid arthritis by direct ultracentrifugal examination. This material migrated as a gammaglobulin electrophoretically, had a sedimentation rate of approximately $22 \mathrm{~S}$ and could be dissociated into two fractions with sedimentation coefficients of $7 \mathrm{~S}$ and $19 \mathrm{~S}$.

Evidence was obtained of a relationship between the $22 \mathrm{~S}$ complex and four of the commonly-used serological tests. In whole sera the titres generally paralleled the amount of the $22 \mathrm{~S}$ component, although some exceptions were encountered. Density gradient centrifugation showed that each of these serological activities sedimented with fractions of high molecular weight. Dissociation of the $22 \mathrm{~S}$ material followed by density gradient ultracentrifugation resulted in 19S material which was highly active in the serological tests.

Further dissociation could be accomplished with mercapto-ethanol and cysteine which split disulphide linkages. This resulted in a loss of serological activity.

Analyses of the precipitate formed on the addition of Fraction II gamma-globulin to rheumatoid sera indicated that it consisted of approximately 50 per cent. 19S material. The latter isolated by centri- $\square$ fugation was active in the sheep cell agglutination as well as in the other rheumatoid tests.

The accumulated evidence suggests that the rheumatoid factors are proteins closely related to other 19S gamma-globulins and to the 19S antibodies, and that they exist in serum and plasma complexed to another type of protein.

\section{REFERENCES}

Cecil, R. L., Nicholls, E. E., and Stainsby, W. J. (1931), Amer. J. med. Sci., 181, 12.

Deutsch, H. F., and Morton, J. I. (1957). Science, 125, 600.

Epstein, W., Johnson, A., and Ragan, C. (1955). Proc. Soc. exp. Biol.' (N.Y.), 91,235

Franklin, E. C. Holman, H. R., Müller-Eberhard, H. J., and Kunkel, H. G. (1957). J. exp. Med., 105, 425.

and Kunkel, H. G. (1957). J. Immunol, 78, 11.

Heller, G., Kolodny, M. H., Lepow, I. H., Jacobson, A. S., Rivera, $\omega$ M. E., and Marks, G. H. (1955). J. Immunol., 74, 340.

Müller-Eberhard, H. J., Kunkel, H. G., and Franklin, E. C. (1956). Proc. Soc. exp. Biol. (N.Y.), 93, 146.

Ryle, A. P., and Sanger, F. (1955). Biochem. J., 60, 535.

Singer, J. M., and Plotz, C. M. (1956). Amer. J. Med.. 21, 888.

Svartz N. and Schlossmann, K (1954) Acta med scand, 149, 83

Walter M. V Schlossmann, K. (1954). A Acia med. scand., 149, 83. (N.Y.), 92, 198.

Ziff, M., Brown, P., Lospalluto, J., Badin, J., and McEwen, C. (1956). Amer. J. Med., 20, 500 .

Rélations des protéines à poids moléculaire élevé avec les réactions sérologiques dans l'arthrite rhumatismale

\section{RÉSUMÉ}

Un complexe de protéines au poids moléculair insolitement élevé fut décelé dans les sérums de certains malades atteints d'arthrite rhumatismale par examen direct à l'ultracentrifugueur. Ce produit se mouvait électrophorétiquement comme une gamma-globuline, avait une vitesse de sédimentation d'environ $22 \mathrm{~S}$ et pouvait être dissocié en deux fractions aux coefficients de sédimentation de $7 \mathrm{~S}$ et $19 \mathrm{~S}$.

On obtint des preuves qu'il y avait un rapport entre le complexe $22 \mathrm{~S}$ et quatre des réactions sérologiques communément employées. Dans les sérums complets les titres étaient généralement parallèles à la quantité du composant $22 \mathrm{~S}$, bien que quelques exceptions fussent notées. La centrifugation par échelle de densité montrait que chacune de ces activités sérologiques sédimentait avec des fractions de haut poids moléculaire. La dissociation du produit $22 \mathrm{~S}$, suivie d'ultracentrifugation par échelle de densité, aboutissait à un produit 19S qui était extrêmement actif dans les réactions sérologiques.

Une dissociation plus prononcée pouvait être obtenue à l'aide de mercaptoethanol et de cystine qui brisaient le lien disulfurique. Ceci aboutissait à une perte d'activité sérologique.

Des analyses du précipité formé à l'addition de la fraction II de la gamma-globuline aux sérums rhumatismaux indiquaient qu'il consistait d'environ 50 pour cent de produit 19S. Ce dernier, isolé par centrifugation, était actif dans l'agglutination des globules de mouton comme dans les autres tests rhumatismaux.

Les données accumulées suggèrent que les facteurs rhumatismaux sont des protéines étroitement apparentées aux autres globulines gamma 19S et aux anticorps 19S, $\mathcal{S}$ et qu'elles existent dans le sérum et le plasma sous forme d'un complexe avec un autre type de protéine. 
Relación de proteinas de peso molecular alto con las reacciones serológicas en la artritis reumatoide

\section{SUMARIO}

Un complejo de proteinas de peso molecular insólitamente alto fué encontrado en los sueros de ciertos enfermos con artritis reumatoide por examen directo a la ultracentrifugadora. Esta substancia se movía electroforéticamente como una gama-globulina, tenía una velocidad de sedimentación de cerca de $22 \mathrm{~S}$ y podía disociarse en dos fracciones con coeficientes de sedimentación de 7S y de 19S.

Los datos obtenidos muestran una relación entre el complejo 22S y cuatro de las reacciones serológicas comunamente empleadas. En los sueros completos las cifras fueron generalmente paralelas a la cantidad del componente $22 \mathrm{~S}$, pero se notaron algunas excepciones. La centrifugación por escala de densidad mostró que cada una de estas actividades serológicas sedimentaba con fracciones de peso molecular alto. La disociación del producto $22 \mathrm{~S}$, seguida de ultracentrifugación por escala de densidad, resultaba en el producto $19 \mathrm{~S}$, que era muy activo en las reacciones serológicas.

Se podía obtener una disociación más pronunciada con la ayuda de mercaptoetanol y de cistina, que rompían el lazo disulfúrico. Esto resultaba en la pérdida de actividad serológica.

El analisis de precipitado formado al añadir la fracción II de la gama-globulina a los sueros reumáticos indicó que éste consistía aproximadamente de un 50 por ciento del producto 19S. Este último, aislado por centrifugación, fué activo en la aglutinación de los glóbulos de oveja asi como en otros tests reumáticos.

Los datos recogidos sugieren que los factores reumáticos son proteinas estrechamente relacionadas a otras gama-globulinas 19S y a anticuerpos 19S que existen en el suero y en el plasma en forma de complejo con otro tipo de proteina. 